\title{
Why ARe Jobs Designed The Way They ARE?*
}

\author{
Cindy Zoghi \\ Bureau of Labor Statistics \\ zoghi.cindy@bls.gov \\ Alec Levenson \\ University of Southern California \\ alevenson@marshall.usc.edu \\ Michael Gibbs \\ University of Chicago GSB \\ Institute for the Study of Labor (IZA) \\ mike.gibbs@ChicagoGSB.edu
}

\begin{abstract}
March 4, 2005
Keywords: job design, organization design, specialization, job enrichment, intrinsic motivation
\end{abstract}

JEL classifications: M5, M50, J2, J24, L23

\begin{abstract}
${ }^{*}$ The data used in this paper are restricted-use; we thank Brooks Pierce for his guidance in analyzing them. We thank John Abowd, Gary Becker, John Boudreau, Susan Cohen, Jed Devaro, Alfonso Flores-Lagunes, Kathryn Ierulli, Ed Lawler, Canice Prendergast, and workshop participants at the American Economics Association Annual Meeting, Århus School of Business, BLS, Cornell, the NBER Summer Institute, the Society of Labor Economists, Universidad Carlos III de Madrid, and USC for their comments. Michael Gibbs gratefully acknowledges the hospitality of the Center for Corporate Performance at the Århus School of Business, and generous funding from the Otto Mœnsted Foundation. All views expressed in this paper are those of the authors and do not necessarily reflect the views or policies of the U.S. Bureau of Labor Statistics.
\end{abstract}




\title{
Why Are Jobs Designed The WAy They Are?
}

\begin{abstract}
In this paper we study job design. Will an organization plan precisely how the job is to be done ex ante, or ask workers to determine the process as they go? We first model this decision and predict complementarity between these job attributes: multitasking, discretion, skills, and interdependence of tasks. We argue that characteristics of the firm and industry (e.g., product and technology, organizational change) can explain observed patterns and trends in job design. We then use novel data on these job attributes to examine these issues. As predicted, job designs tend to be 'coherent' across these characteristics within the same job. Job designs also tend to follow similar patterns across jobs in the same firm, and especially in the same establishment: when one job is optimized ex ante, others are more likely to be also. There is some evidence that firms may segregate different types of job designs across different establishments.
\end{abstract}




\section{Introduction}

Job design is a fundamental issue in organization design. Which tasks should be put together in the same job, what skills and training are needed, what decisions the employee is allowed to make, with whom the employee works, and related questions are crucial for efficiency and innovation. These issues have long been a focus of social psychology, which has a large literature on effects of job "enrichment" on intrinsic motivation. By contrast, job design has been underemphasized in economics, with some notable exceptions such as Adam Smith's (1776) discussion of specialization.

Empirical evidence suggests that there are patterns and trends in job design. For example, the management research literature and evidence from large organizations (Cohen \& Bailey, 1997; Lawler, Mohrman \& Benson, 2001) suggest a trend in recent decades toward teams and human resource practices associated with job "enrichment"; i.e., multitasking instead of specialization, and greater employee discretion. In addition, this job design approach seems to be positively associated with organizational change (Milgrom \& Roberts 1990, 1995; Caroli \& Van Reenen 2001). Finally, a substantial literature argues that organizational change in recent years has been skill-biased, leading to increasing returns to skills and a greater emphasis on higher-skilled workers in firms that have undergone change (Autor, Katz \& Krueger 1998; Bresnahan, Brynjolfsson \& Hitt 1999; Autor, Levy \& Murname 2001; Zoghi \& Pabilonia 2004).

In this paper, we present an economic analysis of job design. We first develop a model based on a simple idea: combining interdependent tasks in a job may enable the worker to learn process improvements. If this effect dominates gains from specialization, then multitasking leads to greater productivity. Learning should be greater for high-skill workers who are given discretion. Thus, interdependence may lead to multitask jobs, and greater discretion and skills.

We then consider the causes of intertask learning. If the firm optimizes ex ante, there is little scope for the worker to learn, and specialization is likely to dominate multitasking. Historically, this has been called "scientific engineering" or "Taylorism." On the other hand, when investments in ex ante optimization have low returns, firms may adopt a continuous improvement approach, designing jobs to optimize worker learning. For example, firms in rapidly changing environments may choose multitasking 
and decentralization because of greater scope for workers to learn new methods. Therefore, job design should be related to such characteristics of the firm's environment--its product, industry, and technology-yielding patterns of job design within firms, and within establishments in the same firm. This can explain trends toward broader job design and greater worker discretion, and the association of job design attributes with organizational change.

The second part of the paper analyzes a unique, nationally representative dataset on job design. The BLS National Compensation Survey measures job design attributes, including multitasking, discretion, skills, and interdependence. As predicted, we find that all four are strongly positively correlated. There is a tendency for firms to choose either a "modern" approach (high on all job design dimensions) or a "classical" approach (low on all dimensions) at the establishment level. This is consistent with our arguments that job design approaches vary with the firm's product and market characteristics. At the firm level, there is a tendency to push job design toward extremes, choosing modern design in some establishments and classical design in others. This is consistent with multi-establishment firms using establishments to isolate modern and classical jobs from each other to maximize the benefits of job design.

\section{A Theory of Job Design}

We now present a simple theory of job design based on Lindbeck \& Snower (2000) and Gibbs \& Levenson (2002). See also Dessein \& Santos (2004) for similar ideas. Output depends on two tasks:

$$
\mathrm{Q}=\mathrm{X}_{1} \cdot \mathrm{X}_{2}^{\alpha}
$$

where $\mathrm{X}_{\mathrm{i}}$ is output from task $\mathrm{i}$, and $\alpha>0$ reflects comparative advantage of the tasks in producing output.

Output on each task depends on the fraction of the worker's time allocated to that task ( $\tau$ for the first task, 1- $\tau$ for the second). If the worker performs both tasks, output also depends on the extent of intertask learning: in performing one task, the worker improves output on the other. For example, a worker who performs both tasks should better understand what to emphasize in performing each task, leading to lower costs or better quality. Exposing a worker to a broader set of tasks also may lead to more innovation and creativity. Using the familiar example of academia, most universities are organized to combine teach- 
ing and research, because in most cases working on each improves work on the other. Similarly, interdisciplinary research is often encouraged because it tends to lead to more creative new research topics.

The extent that output improves on the second task is proportional to time spent on the first task:

$$
\mathrm{X}_{1}=\mathrm{s} \tau+\mathrm{k}(1-\tau)
$$

where $\mathrm{s}=$ the marginal product of time spent on each task, and $\mathrm{k}=$ the degree of intertask learning. The learning effects are not as strong as the direct effects, $\mathrm{s}>\mathrm{k}$.

Workers have skills (innate ability or human capital) h. It is natural to assume that intertask learning is stronger for more skilled workers: $\mathrm{k}=\mathrm{k}(\mathrm{h}), \mathrm{dk} / \mathrm{dh}>0$.

Consider two job design cases for two identical workers. The first is specialization: each task is assigned to a different worker. The second is multitask jobs: each task is assigned to both workers, and output is the sum of the outputs $\mathrm{Q}_{\mathrm{i}}$ for each. As in Becker \& Murphy (1992), there are coordination costs $\mathrm{C}$ if workers are specialized, but none if workers have multitask jobs.

\section{a. Specialized Jobs}

In this case, one worker focuses on task 1 (sets $\tau=1$ ); the other focuses on task 2 (sets $\tau=0$ ). Their work is then combined to make total output. A simple example might be an assembly line. Thus,

$$
\mathrm{Q}_{\text {specialized }}=\mathrm{s}^{1+\alpha}-\mathrm{C} \text {. }
$$

Because output is multiplicative in $\mathrm{X}_{1}$ and $\mathrm{X}_{2}$, there are gains from specialization, as $\tau$ can be set to 0 or 1 rather than forcing a convex combination of time on each task. However, these are offset by coordination costs. When workers specialize, there are no gains from intertask learning.

\section{b. Multitask Jobs}

In this case each worker devotes time to both tasks. Output for worker i is:

$$
\mathrm{Q}_{\mathrm{i}}=(\mathrm{s} \tau+\mathrm{k}(1-\tau))(\mathrm{s}(1-\tau)+\mathrm{k} \tau)^{\alpha}
$$

$\tau$ is chosen to optimize $Q_{i}$ for each worker:

$$
\tau^{*}=\frac{\mathrm{s}-\alpha \mathrm{k}}{(1+\alpha)(\mathrm{s}-\mathrm{k})} ; \quad 1-\tau^{*}=\frac{\mathrm{s} \alpha-\mathrm{k}}{(1+\alpha)(\mathrm{s}-\mathrm{k})}
$$


For there to be multitask jobs with $\tau \in(0,1), \alpha$ cannot be too different from 1 in either direction (so that $\mathrm{s}-\alpha \mathrm{k}>0$, and $\mathrm{s} \alpha-\mathrm{k}>0$ ). Thus we should see multitask jobs only if the relative marginal product of tasks is not too divergent; i.e., if comparative advantage is not too strong.

Given the allocation of time between the two tasks, individual worker output is given by substituting $\tau^{*}$ and $1-\tau^{*}$ into $\mathrm{Q}_{\mathrm{i}}$ above. Total output is twice this for two multitasking workers:

$$
\mathrm{Q}_{\text {multitask }}=2 \alpha^{\alpha}\left(\frac{\mathrm{s}+\mathrm{k}}{1+\alpha}\right)^{1+\alpha} .
$$

For example, if $\mathrm{k}=0$ and $\alpha=1$, then $\mathrm{Q}_{\text {multitask }}=1 / 2 \cdot \mathrm{s}^{2}$, and $\mathrm{Q}_{\text {specialized }}=\mathrm{s}^{2}-\mathrm{C}$, which is greater than $\mathrm{Q}_{\text {multitask }}$ as long as $\mathrm{C}$ is not too large. Comparing (1) and (2), as $\alpha$ diverges from 1 in either direction, specialization is more likely to be the best design because of comparative advantage. ${ }^{1}$

The effects of higher marginal product $\mathrm{s}$ are also ambiguous, since higher $\mathrm{s}$ increases output for both specialized and multitask jobs. The elasticity of output with respect to $\mathrm{s}$ in each case is:

$$
\mathrm{E}_{\text {multitask }}=(1+\alpha)\left(\frac{\mathrm{s}}{\mathrm{s}+\mathrm{k}}\right) ; \quad \mathrm{E}_{\text {specialized }}=(1+\alpha) .
$$

If $\mathrm{k}>0$ (the only reason for multitask jobs), output is more elastic with respect to $\mathrm{s}$ for specialized jobs. So even if multitask jobs are optimal for some range, as s gets very large specialization dominates. Thus, the model does not make a prediction about the incidence of multitasking across hierarchical levels. Empirically, it seems clear that multitasking is more important at higher levels in most firms. One reason might be the increasing importance of coordination at higher levels in the production function, which is beyond the scope of this model (though it would be similar to what we call interdependence below).

We now derive our first result, that multitask jobs are more likely to be optimal, the more important is intertask learning:

\footnotetext{
${ }^{1}$ This analysis understates the advantages of specialization, because we force the ratio of specialized workers on each task to be one-to-one. Allowing firms to deploy different ratios of workers to each task, or to have some multitask and some specialized workers, would improve the firm's ability to exploit differences in productivity $(\alpha)$ across the two tasks. Our goal is to demonstrate factors that might tip the scale toward using multitask jobs, so we ignore this extension.
} 


$$
\frac{\partial \mathrm{Q}_{\text {multitask }}}{\partial \mathrm{k}}>0, \quad \text { while } \quad \frac{\partial \mathrm{Q}_{\text {specialized }}}{\partial \mathrm{k}}=0 .
$$

The result is obvious by inspection of (1) and (2). This is our core argument: multitask jobs imply that workers are more likely to see how different parts of the process fit together. This increases the worker's ability to do both tasks, leading to continuous improvements and innovations. Thus, complex production processes (greater task interdependence) are more likely to use multitask jobs. For workers to learn on the job, multitasking is important because task interdependencies are an important source of inefficiencies in production, and one that is exacerbated by specialization. Thus, the degree of specialization is limited not just by coordination costs (Becker \& Murphy 1992), but also by intertask learning opportunities. ${ }^{2}$

\section{c. The Role of Skills}

More highly-skilled workers will be better able to learn on the job, and exploit their insights to improve production. This idea is captured in our second result: multitask jobs are more likely to be optimal, the higher the worker's skills. Since $\mathrm{dk} / \mathrm{dh}>0$, this follows immediately from (1) and (2). Returns to skills will be higher in more complex work environments, where the scope for intertask learning is higher. This implication of the model is of particular relevance to the discussion of skill-biased technical change. Much of that literature (Autor, Katz \& Krueger 1998; Goldin and Katz 1998; Autor, Levy \& Murnane 2001) has focused on the relationship between technology change and wages. Considering the role of job design characteristics provides further insights into how technology, product and organizational differences influence changes in both job design and wages. For example, our model implies that certain kinds of technology will be skill-biased if they improve intertask learning.

\footnotetext{
${ }^{2}$ Intertask learning can also occur across workers through collaboration, but with coordination costs. A more complex model might consider whether a group can learn more or less effectively than an individual. The individual does not suffer from coordination costs of getting the team to function effectively. However, a well-functioning team might learn more effectively because of the value of different priors, points of view, etc.
} 


\section{d. The Role of Discretion}

Another important job design characteristic is the degree of discretion (decentralization) given to an employee (Ortega 2004, Zoghi 2002). When there is learning in a multitask job, discretion allows the worker to test new methods of production to solve problems and implement improvements (Jensen \& Wruck 1994). For example, suppose the production environment $\mathrm{k}$ (or s, k/s, or $\alpha$ ) is stochastic, and ex ante the firm knows the distribution of $\mathrm{k}$ but not its specific value. If workers perform both tasks, they observe the state of the world before choosing their allocation of time $\tau$, allowing them to observe in real time the relative value of focusing on one task or devoting time to both. If workers are given discretion, they can choose $\tau$ conditional on the state of the world, though at some agency cost D. ${ }^{3}$ Otherwise, the firm chooses $\tau$ without this knowledge. Using the worker's knowledge can improve output:

$$
\mathrm{Q}_{\text {multitask | discretion }} \geq \mathrm{Q}_{\text {multitask | centralization }}
$$

Proof: $\mathrm{Q}_{\text {multitask } \mid \text { centralization }}=\operatorname{argmax}_{\tau}[\mathrm{E}(\mathrm{Q})]=$ expected output with $\tau$ chosen over the entire distribution of the unknown state of the world. $Q_{\text {multitask } \mid \text { discretion }}=\operatorname{argmax}_{\tau}[\mathrm{Q} \mid$ state of the world $]$. The $\tau$ chosen to maximize expected output can result in actual output no better than when the state of the world is known. If these benefits outweigh the agency costs $\mathrm{D}$, a multitask worker will be given discretion.

Moreover, discretion will tend to be more valuable in more uncertain production environments. From (2), Q is convex in $\mathrm{s}, \mathrm{k}, \mathrm{s} / \mathrm{k}$, and $\alpha$. Therefore, expected output will be higher when variance in any of these parameters can be exploited by the worker (by Jensen's inequality). Unfortunately, solving for the optimal time allocation $\tau^{*}$ when production is stochastic does not yield closed form solutions, even for simple cases (e.g., binary k or $\alpha$ ). However, putting together these ideas and the special case in (4) above,

\footnotetext{
${ }^{3}$ Our goal here is not to model agency costs, so we assume the simplest form. One might extend the argument to predict that worker incentives will be complementary with discretion (Ortega 2004). Dessein \& Santos (2004) consider this possibility, and show that increasing agency costs with greater discretion may make the relationship between multitasking and interdependence non-monotonic. Our data do not contain information on compensation policies so we ignore that possibility.
} 
it seems reasonable to predict that discretion is complementary with multitasking, especially in more uncertain environments.

More generally, we might model the worker receiving an imperfect signal about k (or k/s), but with greater precision than the firm; a similar result should follow. In that case, a natural extension would be to assume that the precision of the signal is an increasing function of the worker's skill h. If so, skills and discretion would be directly complementary. In the simpler case, both are complements with multitask jobs when there is intertask learning.

Regardless, the story fits together nicely: multitasking allows the worker to see interdependencies between tasks, learning ways to improve output, lower costs, or improve quality. We can interpret k (or $\mathrm{k} / \mathrm{s}$ ) as measuring the degree of task interdependence, or the extent to which doing both tasks provides learning opportunities on the job. Thus, environments with greater interdependence between tasks are more likely to see multitask jobs, etc. If production is stochastic, workers may have better information than management about the state of intertask learning or comparative advantage. Such worker knowledge arises only from multitasking, because it involves the relative returns to allocating effort across multiple tasks. Discretion allows the worker to change emphasis dynamically, exploiting this knowledge to maximize productivity improvements from intertask learning. Higher skills may reinforce learning on the job, and observing the state of nature. Putting these all together yields our first empirical prediction:

\section{There will be positive relationships between the degree of multitasking, discretion, em- ployee skills, and interdependence.}

In summary, “modern” job design emphasizes decentralized, continuous improvement by skilled workers with multitasked jobs. "Classical" job design emphasizes centralized, ex ante optimization, resulting in specialization, low discretion, and low skills. If opportunities for learning on the job are large enough, the balance may tip toward multitasking, etc. Thus, factors leading to greater intertask learning $\mathrm{k}$ will affect the firm's approach to job design. 


\section{e. Relationship to Intrinsic Motivation}

The predictions to this point are very similar to those from the social psychology literature on intrinsic motivation. The most well-known versions of this work (Hackman \& Lawler 1971; Hackman \& Oldham 1976) argue that task or skill variety drive intrinsic motivation, because the job is more intellectually challenging to the worker. Indeed, Adam Smith recognized that a cost to specialization is workers may be bored and less motivated. This leads to multitask jobs and to "autonomy," which amounts to giving the employee discretion. However, multitasking and discretion arise in the model in this paper from a different mechanism, intertask learning, which requires no assumptions about worker psychology.

The model can easily accommodate intrinsic motivation. If the marginal disutility of effort is lower when the worker performs both tasks, this yields an additional benefit to multitasking: intrinsic motivation could be modeled as increasing coordination costs $\mathrm{C}$ of specialization. However, we purposely do not consider intrinsic motivation. Although we believe that many workers are intrinsically motivated by multitask jobs, the intertask learning mechanism should hold regardless of any psychological effects, and is nicely complementary with the psychological explanation. The psychology story implies that multitask jobs will increase the extent to which workers are intellectually engaged in their work: thinking and curious about what they are doing. If so, this should only increase the degree of intertask learning.

\section{f. The Role of Product, Technology, and Other Firm Characteristics}

Consider ex ante optimization of production methods as an investment by the firm. A greater expected return on this investment should induce more scientific engineering, specialization, etc. The expected return depends on the degree to which it uncovers methods close to the optimum, and the extent to which the efficiency gains are expected to be reaped in the future. These depend on the complexity, predictability, and stability of the firm's product and environment.

The first relevant characteristic of the product or process is complexity. Those that are more com-

plex (e.g., more parts; modules in a software program; broader product line) are more difficult to perfect ex ante. The cost of optimizing the manufacture of a tin can (less than half a dozen parts) is substantially 
lower than optimizing the manufacture of a diesel engine (2000 or more parts). Moreover, in the diesel engine, the parts have to work together well - there is high interdependency. Such interdependencies tend to be the kind of situations where ex ante optimization is more difficult, quality problems arise, etc.

A second important characteristic of the production process is the extent to which it is unpredictable. Consider management consulting. Each client engagement is typically different from the last. Some processes and methods can be reapplied, but new methods or applications often need to be developed. Moreover, judgment as to what methods to apply may be required. To the extent that situations arise over and over, the consulting firm may be able to develop standard methods, and provide employees with a menu of choices from which to select. However, if any of the work is idiosyncratic and unforeseeable, some optimization will have to occur in real time.

A third important production process characteristic is stability. This plays out both backward and forward in time. The longer a product has been produced with few or no changes, the more is known about how to make it efficiently. The longer the firm expects to make the same product, the greater the expected returns on ex ante optimization, leading to greater investments in ex ante optimization.

These factors (complexity / interdependence, predictability, and stability) influence the return on investments in ex ante optimization of methods. If the return is small, the firm will invest less in ex ante optimization, and there are greater possibilities for employees to engage in continuous improvement. Continuous improvement is more likely to be successful with a "modern" approach to job design. These ideas should help explain patterns of job design across firms:

\section{Firms will tend toward choosing a "pure" job design approach (i.e., applying one job de- sign approach to all jobs) within the organization.}

Thus we expect a clustering of high levels of multitasking, discretion, skills, and interdependence within some firms, medium levels at other firms, and low levels at still other firms. In social psychology, Porter, Lawler and Hackman (1975) make a similar assertion. Note though that high, medium, and low are relative terms. The prediction is about multitasking, etc. relative to their occupational norms. 
Note that we do not conclude that modern jobs are optimal for all establishments. This may explain the often conflicting results found in studies of the effect of adoption and use of "high performance work systems" on productivity and profitability of organizations (Applebaum and Batt 1994; Cappelli and Neumark 2001; MacDuffie 1995; Ichniowski and Shaw 1995; Ichniowski, Shaw \& Prennushi 1997). Many of these studies find that while the adoption of a single policy does not affect measurable outcomes, there are complementarities between policies that can have real effects.

This logic might also explain a recent trend toward "modern” jobs (Caroli \& Van Reenen 2001). The last few decades have exhibited rapid change, due to modern manufacturing and flexible production methods, information technology and technological change, shorter product cycles, and increasing emphasis on customization and complex product lines (Milgrom \& Roberts 1990, 1995). All reduce the returns from investing in industrial engineering, and increase the returns to continuous improvement. In a changing environment, there is greater scope for workers to develop improvements and aid implementation of change, because old methods are less likely to be optimal.

Such patterns should be stronger within establishments than within firms as a whole. At a naïve level, product attributes are likely to be more similar within than across establishments. Less naïvely, establishments are groupings of employees chosen by the firm. Because workers are grouped together by choice, it is more likely that the products, customers, technology, etc. that they work with are the same as their colleagues in the same establishment, compared to employees randomly chosen from the same firm but different establishments. Moreover, if workers are put together at a site when their work is highly interdependent, establishments can in a sense be viewed as teams. If their work is interdependent, then it is even more likely that product and technology attributes will affect them similarly. Thus, we predict that:

\section{The tendency toward choosing a "pure" job design should be stronger at the establish- ment level than at the firm level.}

We now turn to a description of the data that we employ to test these ideas. 


\section{Data}

Our empirical analyses use a novel dataset that contains information on job design from a nationally representative sample of establishments in the U.S. The National Compensation Survey (NCS) is a restricted-use dataset collected by the Bureau of Labor Statistics. It covers the non-agricultural, nonfederal sectors of the US economy. Our data are from 1999. The data are collected by field economists who visit sampled establishments and randomly select 5-20 workers from the site's personnel records, depending on establishment size. Through interviews with human resources representatives, detailed information about the jobs those workers hold is obtained.

The data include information on occupation and union status of each job, industry, whether the establishment is privately owned or public (state or local government), earnings data, and an indicator for use of incentive pay. No demographic information about the worker is collected. The most unusual feature of the dataset is the "leveling factors," which are intended to measure various job design attributes consistently across occupations. These factors are based on the Federal Government's Factor Evaluation System, which is used to set Federal pay scales. ${ }^{4}$ There are ten different leveling factors, or job design attributes, of which we use five in this paper: Knowledge; Supervision Received; Guidelines; Complexity; and Scope \& Effect. Here we provide a brief synopsis of each and how they correspond to the concepts from our theoretical discussion. All are measured on Likert scales with ranges varying from 1-3 to 1-9.

1. Knowledge: This measures the nature and extent of applied information that the workers are required to possess to do acceptable work - this is quite similar to the general notion of human capital. 13 correspond roughly to blue collar levels of skills. 4 is at the level of an apprenticeship. 5 is at the level of a college graduate, and so on. Thus, larger values imply greater Knowledge. This factor corresponds quite well to our Skills job design attribute.

\footnotetext{
${ }^{4}$ For a detailed description of the NCS, see Pierce (1999).
} 
2. Supervision Received: This measures the nature and extent of supervision and instruction required by the supervisor, the extent of modification and participation permitted by the employee, and the degree of review of completed work. Larger values correspond to less Supervision. Values of 1-2 indicate substantial supervisory control with minimal employee input. 3 implies some autonomy for the employee to handle problems and deviations. 4-5 indicate that general objectives are set by the supervisor while the worker has more responsibility for implementation and there is little review of the completed job. This factor corresponds to some dimensions of Discretion in our discussion above. We use it, along with the next factor, to proxy for that concept.

3. Guidelines: Measures how specific and applicable the guidelines are for completing the work, and the extent of judgment needed to apply them. As with Supervision Received, larger numbers correspond to less use of Guidelines. 1-2 signify that detailed guidelines are available that are applicable in most situations that are likely to arise. 3 indicates that, while guidelines are available, the worker must judge whether or not they are applicable, and how to adapt them. 4-5 indicate that few guidelines are available or applicable to completing this job. Thus, we interpret both Supervision Received and Guidelines as indicators of our concept of Discretion. ${ }^{5}$

4. Complexity: Complexity measures two things: the extent to which the job has multiple dimensions, in terms of the nature, number, variety and intricacy of tasks or processes; and the extent to which the job has unpredictability, due to the need to assess unusual circumstances, variations in approach and the presence of incomplete or conflicting data. The former is closer to what we mean by multitasking as the opposite of specialization, though unpredictability also suggests variation in tasks. Moreover, Complexity is positively associated with interrelationships between tasks. In our discussion of job enrichment, we argued that an important reason for multitasking is to design jobs so that employees see complex in-

\footnotetext{
${ }^{5}$ An interesting way to think about Guidelines and Supervision Received is that Guidelines is a form of ex ante control, useful for foreseeable contingencies, while Supervision Received is a form of control used for more unpredictable or idiosyncratic events.
} 
teractions between the most complementary tasks. Thus, the NCS Complexity corresponds reasonably well to our concept of Multitasking.

5. Scope \& Effect: Scope \& Effect measures the extent to which the employee's work has impacts on activities and persons in (and beyond) the organization, for example by affecting the design of systems, the operation of other organizations, the development of programs or missions. As Scope \& Effect gets larger, the impacts get larger. This measures the interdependence of a job with other processes and jobs in and beyond the organization, rather than interdependence between tasks within the same job. However, it seems likely that greater interdependence between jobs will be positively correlated with greater interdependence between tasks within jobs, indicating that overall interdependence is higher. We interpret this as a proxy for Interdependence. ${ }^{6}$

\section{Results}

\section{a. Bivariate Relationships between Job Characteristics}

Table 1 shows the Spearman rank-order correlations between the five factors. The correlations are high, consistent with our first prediction that there should be positive relationships between multitasking, discretion, skills, and interdependence across jobs.

Table 2 replicates the bivariate relationships from Table 1 using ordered probit analysis, predicting Multitasking as a function of both measures of discretion (Guidelines and Supervision), Skills, and Interdependence; Guidelines as a function of Supervision, Skills, and Interdependence; Supervision as a function of Skills and Interdependence; and Skills as a function of Interdependence. Each cell in the table represents a separate regression, with the row naming the dependent variable and the column naming the independent variable. The first number in each cell shows the estimated ordered probit coefficient.

Each model includes controls for both union and nonprofit status. The top panel is for the entire sample. The middle and bottom panels have non-managers and managers, respectively. Appendix Table

\footnotetext{
${ }^{6}$ Our main results are essentially unchanged even without the inclusion of this variable in the analysis.
} 
A1 repeats the ordered probits adding first a set of indicators for the establishment's primary industry and then the job's primary occupation.

Because of large sample sizes, coefficients always have high levels of statistical significance, so standard errors are not included. A more informative statistic is the pseudo- $\mathrm{R}^{2}$ (in parentheses below each coefficient): $1-\left(\mathrm{LL}_{\text {Full model }} / \mathrm{LL}_{\text {Constant only }}\right)$, where $\mathrm{LL}$ is the log-likelihood. The pseudo- $\mathrm{R}^{2}$ shows the extent to which the variance in the dependent variable is "explained" by the model.

In all the models in the top panel of Table 2 for the full sample, the Pseudo- $\mathrm{R}^{2}$ indicates a strong relationship between the factors. Close to half the variance in Multitasking is explained by either of the Discretion variables and by Interdependence. Not surprisingly, there is also a strong positive relationship between the two measures of Discretion. More than half the variance in Guidelines is explained by Interdependence. The relationships between Skills and Multitasking, Skills and Discretion, and Skills and Interdependence are also positive, but are not as strong. Overall, Table 2 presents strong evidence consistent with the first prediction.

In addition to the results for the full sample at the top of Table 2, the results for the nonmanagerial and managerial samples are reported in the middle and bottom of the table. The first point of note is that the basic patterns are the same: strong positive correlations among all job design characteristics. Second, the correlations among Skills and each of Multitasking, Guidelines or Supervision are much stronger within the managerial sample than within the non-managerial sample.

The fact that the evidence supports the theory for both the managerial and non-managerial samples, and that the relationships are stronger when controlling for occupations, is particularly noteworthy in light of previous empirical evidence. The examples studied most often come from manufacturing, and are closely tied into the discussion in recent years of the impact of human resource practices on productivity and profitability (Huselid 1995; MacDuffie 1995; Ichniowski, Shaw \& Prennushi 1997; Cappelli \& Neumark 2001). The disproportionate focus on manufacturing is understandable given the intellectual heritage and framework established by Taylor (1923), and the ease of measuring productivity in manufactur- 
ing. But the theory does not require a manufacturing setting, as the more recent research on service environments demonstrates (Batt 2002; Batt \& Moynihan 2002). ${ }^{7}$

\section{b. Multivariate Relationships between Job Characteristics}

The results in Tables 2 and A1 provide evidence that pairs of job design attributes are complementary. A stronger test focuses on the extent to which they cluster together as a group so that job designs are "coherent" - all four dimensions high, all medium, or all low. To examine this we first center the values for each job around the median for each three digit occupation. This allows us to consider a job as high, medium or low along each dimension, relative to its occupational peers nationwide. The distribution above and below the occupation-specific median is in the top half of Table 3 . In the bottom half of Table 3 we assign values of 1,2 and 3, respectively, to values below, at, and above the median for each factor. ${ }^{8}$ There are 81 possible combinations of the four characteristics. There are nine possible sums; Table 4 shows the percentage of jobs with all low values, all high, all medium as well as all other possible sums. The standard error of each percentage is in parentheses in the second column under the mean.

The strong test of the extent to which firms choose between classical and modern job designs is provided by comparing the percentage of jobs with all low or all high values to the expected percentage if job characteristics were randomly assigned based on their univariate frequency distributions from Table 3. For example, the expected percent of workers with all low values equals the product of the percentages of jobs below the median for each characteristic: $(0.3624) \cdot(0.3332) \cdot(0.1927) \cdot(0.3093)=0.0072$ (third column). The corresponding expected percent having all high values is 0.0212 . In both cases the actual fraction of jobs with all low or all high is much larger; the differences are significant with p-values $<0.01$. Thus the percentages of jobs that are "all classical" or "all modern" are much greater than we would ex-

\footnotetext{
${ }^{7}$ While the point estimates in Table 2 versus Table A1 do not change much when controlling for industry fixed effects, the explained variation increases. The increase in explanatory power for each of the models is significant with a p-value $<.00001$ in each case. Thus industry differences do account for part of the relationship between job design attributes; they just do not account for much of the positive correlations.

${ }^{8}$ For the remainder of the paper we use Guidelines as the sole proxy for Discretion. Results are similar for Supervision Received.
} 
pect to see if job characteristics were randomly distributed within each job While much of the prior literature has focused on these extremes (all low; all high), note too that one quarter of all jobs fall into the allmedium values category. This is an extremely large percentage relative to what we would expect from random assignment $(0.87 \%$, third column). These results are strong evidence for the theory, and show a marked tendency toward coherent job designs.

\section{c. Effects of Establishment Characteristics on Job Characteristics}

We have argued that no single job design strategy is necessarily optimal for all types of establishments, but that characteristics of the environment, such as product complexity, stability, and predictability will affect the choice of job design. Although these characteristics are largely absent from our data, we can determine whether unionization, establishment size and non-profit status affect job design. We thus model the probability that a job is "all modern" or "all classical" using logit regressions. Table 5 shows the results of this analysis. The second and fourth columns include a full set of industry indicators. ${ }^{9}$

Unionized jobs are much less likely to be "all classical" yet also less likely to be "all modern". The former is consistent with unions' traditional negative views of classical job design. The latter is consistent with the conventional wisdom that unions resist change, and to wider differences in compensation among members. Modern job design has potential benefits to employees in upgraded skills and potentially higher wages. But making that change can threaten the probability that existing union workers will keep their jobs, and might widen the dispersion in earnings among members. Nonprofits similarly reduce the probability that a job is either "all modern" or "all classical."

Larger establishments are more likely to choose modern job design and less likely to choose classic job design. This is consistent with the model, which argues that the specialized output can exceed the multitask output when coordination costs are large. In larger establishments there are often more hierar-

\footnotetext{
${ }^{9}$ One criticism of our findings might be that they are driven not by intertask learning, but instead by firms designing jobs to generate intrinsic motivation as in the social psychology literature. However, the fact that job design patterns vary systematically
} 
chical levels, making information transfer slower and more difficult, resulting in higher coordination costs. Finally, it is important to note that although these establishment characteristics alone do not explain a large fraction of the variance in the probability a job is modern or classical, the industry indicators add substantial explanatory power to the model. This suggests that other characteristics of the industry, such as product complexity and stability, do strongly affect an establishment's choice of job design.

\section{d. Similarity of Job Designs within Firms and Establishments}

We now turn to analysis of our second and third predictions, that job designs will tend to be similar within firms, and even more so within establishments. For predictions 2 and 3, the relevant comparison for a job is not to all other jobs in the economy, but to other jobs in the same establishment or firm. We re-estimate the logits of the previous section, including as regressors the percentages of other jobs in the establishment or firm that fall into each of the 81 unique combinations of the four job characteristics. For ease of interpretation, Table 6a reports the results when all jobs with common combinations are grouped together. For example, the "3L, 1M" group includes four subgroups: LLLM, LLML, LMLL and MLLL. ${ }^{10}$ We predict that the probability that any one job is "all modern" is positively related to how many other jobs in the establishment and/or the firm are "all modern." For the firm variables, the percentages are calculated using jobs at other establishments in the same firm, excluding jobs at the same establishment. Thus firms with only one establishment are excluded from the analysis in Table 6a. The first sets of columns predict the probability of a classical (LLLL) job, both with and without 3 digit industry controls. The second sets of columns predict the probability of a modern (HHHH) job.

The results in Table 6a are consistent with the second prediction. The probability of a classical job is correlated positively with the percentage of other jobs in the establishment that are classical (first row), and negatively with the percentage of other jobs in the establishment that are modern (last row). Similarly,

across different industries suggests that product or industry characteristics matter, which is strong evidence in favor of the intertask learning explanation. Of course, it is most likely that both mechanisms play a role.

${ }^{10}$ For sake of comparison, Appendix Table A2 contains the results when all 81 unique categories are entered separately. 
the probability of a modern job is correlated positively with the percentage of other jobs in the establishment that are modern, and negatively with the percentage of other jobs in the establishment that are classical. There are similar positive, but smaller, correlations between $\operatorname{Pr}($ LLLL) and many of the jobs that are "almost all" classical (3L1M) and "mostly classical" (2L2M; 1L3M). The opposite is true for $\operatorname{Pr}(\mathrm{HHHH})$ and jobs that are almost $(3 \mathrm{H} 1 \mathrm{M})$ or mostly $(2 \mathrm{H} 2 \mathrm{M} ; 1 \mathrm{H} 3 \mathrm{M})$ modern. Jobs that mix both high and low characteristics $(3 \mathrm{~L} 1 \mathrm{H} ; 2 \mathrm{~L} 2 \mathrm{H} ; 1 \mathrm{~L} 2 \mathrm{M} 1 \mathrm{H}$; etc.) are much less likely to be positively correlated with either $\operatorname{Pr}($ LLLL) or $\operatorname{Pr}(\mathrm{HHHH})$ : none of those coefficients have $\mathrm{p}$-values $<0.05$. Thus, firms tend to choose pure job design approaches, opting for many jobs to be either high on all dimensions, or low on all dimensions. This is consistent with prediction 2 .

To a lesser degree firms make the same choice across establishments. This is consistent with prediction 3, but perhaps more importantly, provides evidence that respondent bias is not the explanation for correlations between characteristics of a job with those of other jobs in the establishment. Although we are concerned that a single human resource representative describing all sampled jobs in the establishment may scale up or down all responses, jobs across establishments within a single firm are described by separate individuals. If job design were not clustered within an establishment but merely appeared to be so due to respondent bias, we would not expect to find peer effects for other workers within the firm but outside the establishment—-such effect confirms that respondent bias is not driving the results. ${ }^{11}$

Two additional patterns are worth noting in Table 6a. First, having many modern jobs in the same establishment reduces the probability that a job will be classical. At the same time, a high percentage of modern jobs in the other establishments in the firm increases the probability that a job will be classical. This suggests that firms isolate similar jobs in the same establishment and also push job design toward the extremes, away from the middle. This pattern disappears when controlling for industry differences across

\footnotetext{
${ }^{11}$ A different response bias, in which some occupations are rated systematically higher than others even if they should not be, is already controlled for by differencing observed values for each job design attribute from the 3 digit occupation-specific mean.
} 
establishments. Thus, such clusters of establishments are concentrated in some industries and not others, and this pattern likely is related to differences in product, technology and/or organizational change. ${ }^{12}$

Second, some within-establishment correlations get stronger when controlling for industry. Specifically when predicting $\operatorname{Pr}(\mathrm{LLLL})$, coefficients on the fraction of jobs that are $\mathrm{HHHH}$ and (3H1M) get more negative; and when predicting $\operatorname{Pr}(\mathrm{HHHH})$ coefficients on the fraction of jobs that are LLLL and (3L1M) get more negative. This means that the tendency for a firm to segregate modern and classical jobs across its establishments is consistent across industries, though more prevalent in some industries.

Table $6 \mathrm{~b}$ presents the results from predicting $\operatorname{Pr}(\mathrm{MMMM})$, using the same set of regressors as Table 6a. As expected, the probability that a job will be MMMM is strongly correlated with the presence of similar "all medium" jobs in both the establishment and in the firm, with stronger within-establishment than within-firm correlations. Table $6 \mathrm{~b}$ shows the same within-firm, across-establishment segregation of dissimilar jobs. In the case of "medium" jobs in Table $6 \mathrm{~b}$, the segregation occurs for jobs that are only slightly different. For example, the greater the fraction of $(1 \mathrm{H} 3 \mathrm{M})$ jobs in the rest of the firm, the lower the probability of a MMMM job in the same establishment.

\section{e. Within vs. Outside 2-digit Occupation Correlations}

To this point, we have not distinguished between occupations except to control for nationwide differences in the median value for each leveling factor by occupation. An interesting question is the extent to which job design patterns within an establishment are driven by clustering of jobs in similar occupations, where occupations are defined by Census 2-digit classifications. We would expect some within-2digit-occupation clustering, given task interdependencies and the consequent complementarity of such skills in production; for example, grouping modern chemical engineering with modern electrical engi-

\footnotetext{
${ }^{12}$ Note that each establishment is assigned its own industry classification, which may differ from the parent firm's. This means that some of the establishment level (across-industry) variation in the first set of columns represents within-firm variance (across establishments) within large integrated firms. Consequently, when the positive correlation between the fraction of modern jobs elsewhere in the firm and the probability of a job being classical becomes insignificant (when controlling for industry fixed effects), this may partly be due to controlling for the within-firm variance in the large integrated firms.
} 
neering jobs. Less obvious is the prediction of between-2-digit-occupation clustering; for example, grouping modern engineering with modern administrative support jobs. It is reasonable to expect such clustering if the task interdependencies in production are relatively "global" across the entire production process. For the most peripheral tasks, however, we would expect interdependencies to diminish to the point where there are fewer gains from clustering job design attributes; such tasks likely would include non-“core" processes such as janitorial work and food service. One characteristic of truly peripheral tasks is that they should be greater candidates for outsourcing (Abraham and Taylor, 1996).

Table 7 shows the proportion of jobs outside of one's own occupation that have the same job design, for the economy absent one's own firm, for the firm absent one's own establishment, and for the other jobs in the establishment. For the sample of single establishment firms, only the first and third categories are relevant. The clustering of modern and classical jobs is greater at the establishment level than at the firm level and the economy overall. This confirms our findings in Tables $6 a, b$ and suggests that occupational clustering intrinsic to the production process does not entirely drive the job design clustering results. For classical (LLLL) jobs, the establishment-level clustering is the same at single vs. multiestablishment firms. For modern (HHHH) jobs, the establishment-level clustering is much stronger in multi-establishment firms. Thus larger (multi-establishment) firms are much more likely to cluster dissimilar modern jobs together. The degree of clustering of all "medium" jobs, in contrast, is no greater within-firm or within-establishment than in the economy overall.

In Table 8 we perform a more rigorous test of the relative importance of within- and acrossoccupation clustering of job design, by re-estimating the models in Tables 6a, separating each within establishment job design variable into two components: similarly designed jobs within the same occupation, and similarly designed jobs in all other occupations. The results show there is both within- and across-2digit-occupation clustering of job design types at the establishment level. For modern jobs, the coefficients on the percentage of other jobs in the establishment that are modern both within the same 2-digit occupation and in other 2-digit occupations are positive and significant at the $p<.01$ level (bottom row, first two columns). The pattern is the same for classical jobs (top row, fourth and fifth columns). More- 
over, in both cases the within-2-digit-occupation correlation is stronger than the across-2-digit-occupation correlation, indicating that within-occupation clustering is more likely than across occupation clustering, as expected. More important is the fact that across-occupation clustering drives at least part of the results in Table 6a: firms tend to group together jobs that are all modern and all classical, even dissimilar jobs.

To better understand these dynamics, Table 9 presents the analog of Table 7 for modern and classical jobs in multi-establishment firms for each of the 2 digit occupation classifications. This enables an identification of which types of jobs drive the across-occupation clustering results in Table 8. For example, using the overall mean in the first row of column three as the comparison, the occupations for which modern jobs are more likely to be clustered with modern jobs in dissimilar occupations at the establishment level include (a) management related, (b) engineers, (c) mathematicians and computer scientists, (d) natural scientists, (e) engineering technologists, (f) service salespeople, (g) construction workers, (h) machine operators, and (i) other precision workers. In contrast, the occupations for which classical jobs are more likely to be clustered with classical jobs in dissimilar occupations include (a) public administration, (b) mathematicians and computer scientists, (c) natural scientists, (d) teachers, (e) finance and business sales, (f) retail sales, (g) secretaries, (h) record keepers, and (i) assemblers.

Note that the similarities and differences in these two lists give an indication of the extent to which all modern and all classical job designs are used both within and across industries and establishments. Public administration and teaching jobs, for example, are concentrated in a narrow set of industries. Retail sales jobs are concentrated in certain types of establishments within multi-establishment firms. The tendency for classical jobs in these occupations to be concentrated with classical jobs in other dissimilar occupations helps explain the patterns in Table 6a when excluding and including controls for the type of industry. A similar argument can be made for the concentration of modern jobs for occupations such as engineers and construction workers.

In contrast, certain occupations are less likely to cluster with dissimilar occupations along both modern and classical lines, including health related, protective services, food services, building services, personnel services, and vehicle operators. Note that these resemble non-core activities that are likely to be 
found in a broad array of establishments (regardless of industry type), and thus are candidates for outsourcing (Abraham and Taylor, 1996).

\section{Discussion and Conclusions}

In this paper we presented a simple theory of job design that can explain observed trends and patterns in the empirical literature. We posed two rough approaches to job design. In the first approach, the firm uses ex ante optimization of methods. As a result workers are given relatively narrow jobs to exploit gains from specialization and comparative advantage, low discretion, and have relatively low skills. However, ex ante optimization is not always feasible or profitable. When the firm faces greater complexity, unpredictability, or instability, it is less likely to effectively optimize production ex ante. If so, then there is potential for the worker to learn on the job and engage in continuous improvement.

We argued that task interdependence is an important source of both costs of ex ante optimization, and of on-the-job learning. Thus, an alternative to ex ante optimization is continuous improvement, giving workers multitask jobs to take advantage of intertask learning. Higher worker skills and greater discretion are complements to this approach: they facilitate developing new ideas and implementing improvements. Thus, the theory predicts that multitasking, interdependence, discretion, and skills will be positively correlated in the same job. Because the emphasis on ex ante optimization or continuous improvement depends on the firm's complexity, unpredictability, and stability, the firm's product, technology, and industry characteristics should be important factors influencing job design. Finally, this logic implies that there should be patterns of similar job design within firms, and even more so within establishments.

We then analyzed data on job design attributes, using reasonable proxies for our concepts of multitasking, discretion, skills, and interdependence. The results are strongly consistent with our predictions. All four job design attributes are strongly positively correlated. There is a tendency for firms to choose either a modern job design approach - high on all four job design characteristics - or a classical job design approach - low on all four, but not both (at the establishment level). This is consistent with our argument that job design approaches vary with the firm's product and market characteristics. At the firm 
level, in contrast, there is a tendency to push job design toward extremes, choosing modern job design in some establishments and classical job design in others. This is consistent with multi-establishment firms using establishments to isolate different types of jobs (and overall organizational design emphasis on centralized, ex ante v. decentralized, continuous optimization) from each other to capture the benefits of job design while minimizing the potential downsides from doing so.

We find strong evidence that firms choose a particular coherent job design strategy, and that the same strategy is not optimal for all organizations. The current data provide some information on characteristics of the establishment's environment that may affect this choice: larger establishments are more likely to choose modern job design, while unionized and non-profit organizations are less likely to choose either "all classic" or "all modern" job design. There are important differences across industries in the choice of job characteristics. In future work we hope to explore this area more thoroughly to determine whether technological considerations, market structure, competition, uncertainty or product characteristics affect the design of jobs. 


\section{REFERENCES}

Abraham, Katharine G., and Susan K. Taylor. 1996. "Firms' Use of Outside Contractors: Theory and Evidence," Journal of Labor Economics, 14:3, 394-424.

Appelbaum, Eileen, and Rosemary Bat. 1994. The New American Workplace: Transforming Work Systems in the United States. Ithaca, NY: ILR Press.

Autor, David H., Lawrence F. Katz and Alan B. Krueger. 1998. "Computing Inequality: Have Computers Changed the Labor Market?” Quarterly Journal of Economics, 113:4, 1169-1214.

Autor, David H., Frank Levy and Richard J. Murnane. 2001. “The Skill Content of Recent Technological Change: An Empirical Exploration.” NBER Working Paper No. 8337.

Batt, Rosemary. 2002. "Managing customer services: Human resource practices, quit rates, and sales growth." Academy of Management Journal, 45:3, 587-597.

Batt, Rosemary and Lisa Moynihan. 2002. "The Viability of Alternative Call Centre Production Models." Human Resource Management Journal, 12:4, 14-34.

Becker, Gary and Kevin Murphy. 1992. "The Division of Labor, Coordination Costs, and Knowledge.” Quarterly Journal of Economics 107(4): 1137-1160.

Bresnahan, Timothy F., Erik Brynjolfsson and Lorin M. Hitt. 1999. "Information Technology, Workplace Organization and the Demand for Skilled Labor: Firm-Level Evidence." NBER Working Paper No. 7136.

Cappelli, Peter and David Neumark. 2001. "Do 'High Performance' Work Practices Improve Establishment-Level Outcomes?” Industrial \& Labor Relations Review: 737-775.

Caroli, Eve and John Van Reenen. 2001. "Skill-Biased Organizational Change? Evidence From a Panel of British and French Establishments." Quarterly Journal of Economics, CXVI(4): 1449-1492.

Cohen, Susan G. and Diane Bailey. 1997. "What makes teams work: Group effectiveness research from the shop floor to the executive suite." Journal of Management, 23:3, 239-290.

Dessein, Wouter and Tano Santos. 2004. "The Demand for Coordination.” NBER Working Paper No. 10056.

Gibbs, Michael and Alec Levenson. 2002. "The Economic Approach to Personnel Research.” In Shoshana Grossbard-Shechtman and Christopher Clague, eds., Expansion of Economics: Towards a More Inclusive Social Science, New York: M.E. Sharpe.

Goldin, Claudia, and Lawrence F. Katz. 1998. "The Origins of Technology-Skill Complementarity," Quarterly Journal of Economics, 113:3, 683-732.

Hackman, J. Richard and Edward E. Lawler, III. 1971. "Employee Reactions to Job Characteristics." Journal of Applied Psychology 55(3): 256-286.

Hackman, J. Richard, and Greg R. Oldham. 1976. "Motivation through the design of work: Test of a theory." Organizational Behavior and Human Performance, 16, 250-279.

Huselid, Mark. 1995. "The Impact of Human Resource Management Policies on Turnover, Productivity, and Corporate Financial Performance." Academy of Management Review 38(3): 635-672.

Ichniowski, Casey and Kathryn Shaw. 1995. "Old Dogs and New Tricks: Determinants of the Adoption of Productivity-Enhancing Work Practices.” Brookings Papers: Microeconomics 1-65. 
Ichniowski, Casey, Kathryn Shaw and Giovanna Prennushi. 1997. "The Effects of Human Resource Management Practices on Productivity: A Study of Steel Finishing Lines." American Economic Review 87(3): 291-313.

Jensen, Michael and Karen Wruck. 1994. "Science, Specific Knowledge, and Total Quality Management." Journal of Accounting and Economics 18(3): 247-287.

Lawler, Edward E., III, Susan A. Mohrman and George Benson. 2001. Organizing for High Performance: Employee Involvement, TQM, Reengineering, and Knowledge Management in the Fortune 1000. San Francisco: Jossey-Bass.

Lindbeck, Assar and Dennis Snower. 2000. "Multi-task Learning and the Reorganization of Work: From Tayloristic to Holistic Organizations. Journal of Labor Economics 18(3): 353-376.

MacDuffie, John Paul. 1995. "Human Resource Bundles and Manufacturing Performance: Organizational Logic and Flexible Production Systems in the World Auto Industry." Industrial and Labor Relations Review 48: 197-221.

Milgrom, Paul and John Roberts. 1990. "The Economics of Modern Manufacturing: Technology, Strategy, and Organization.” American Economic Review. 80(3): 511-528.

Milgrom, Paul and John Roberts. 1995. "Complementarities and Fit: Strategy, Structure, and Organizational Change in Manufacturing," Journal of Accounting and Economics 19(2-3): 179-208.

Ortega, Jaime. 2004. "Employee Discretion: Stylized Facts for Europe.” Working paper, Universidad Carlos III de Madrid.

Pierce, Brooks. 1999. "Using the National Compensation Survey to Predict Wage Rates." Compensation and Working Conditions. Winter: 8-16.

Porter, Lyman W., Edward E. Lawler, III, and J. Richard Hackman. 1975. Behavior in Organizations, New York: McGraw Hill.

Smith, Adam. 1776. The Wealth of Nations. Reprinted by Modern Library.

Taylor, Frederick. 1923. The Principles of Scientific Management. New York: Harper.

Vogel, Todd and Chuck Hawkins. 1990. "Can UPS deliver the goods in a new world?" Business Week, June 4.

Zoghi, Cindy. 2002. "The Distribution of Decision Rights Within the Workplace: Evidence from Canadian, Australian and UK Establishments" BLS Working Paper No. 363.

Zoghi, Cindy and Sabrina Pabilonia. 2004. "Which Workers Gain from Computer Use?" BLS Working Paper No. 373. 
Table 1.

Correlations Between Job Design Attributes

\begin{tabular}{llllll}
\hline \hline & & \multicolumn{2}{c}{ Discretion } & \multirow{2}{*}{ Skills } & \multirow{2}{*}{ Interdependence } \\
\cline { 3 - 4 } & & Guidelines & Supervision & & \\
\hline \multirow{2}{*}{ Multitasking } & & & & & \\
\multirow{2}{*}{ Discretion } & Guidelines & 0.8475 & 0.8505 & 0.8341 & 0.8485 \\
& Supervision & & 0.8450 & 0.8234 & 0.8701 \\
& Received & & & 0.8274 & 0.8404 \\
Skills & & & & 0.8176 \\
\hline \hline
\end{tabular}

Spearman rank-order correlations between job design attributes. Because sample sizes are so large and significance levels are so high, those statistics are not shown in the tables. Overall sample size $=137,181$; there are 15,349 firms, and 19,791 establishments. 
Table 2.

Unrestricted Relationships Between Pairs of Job Design Attributes

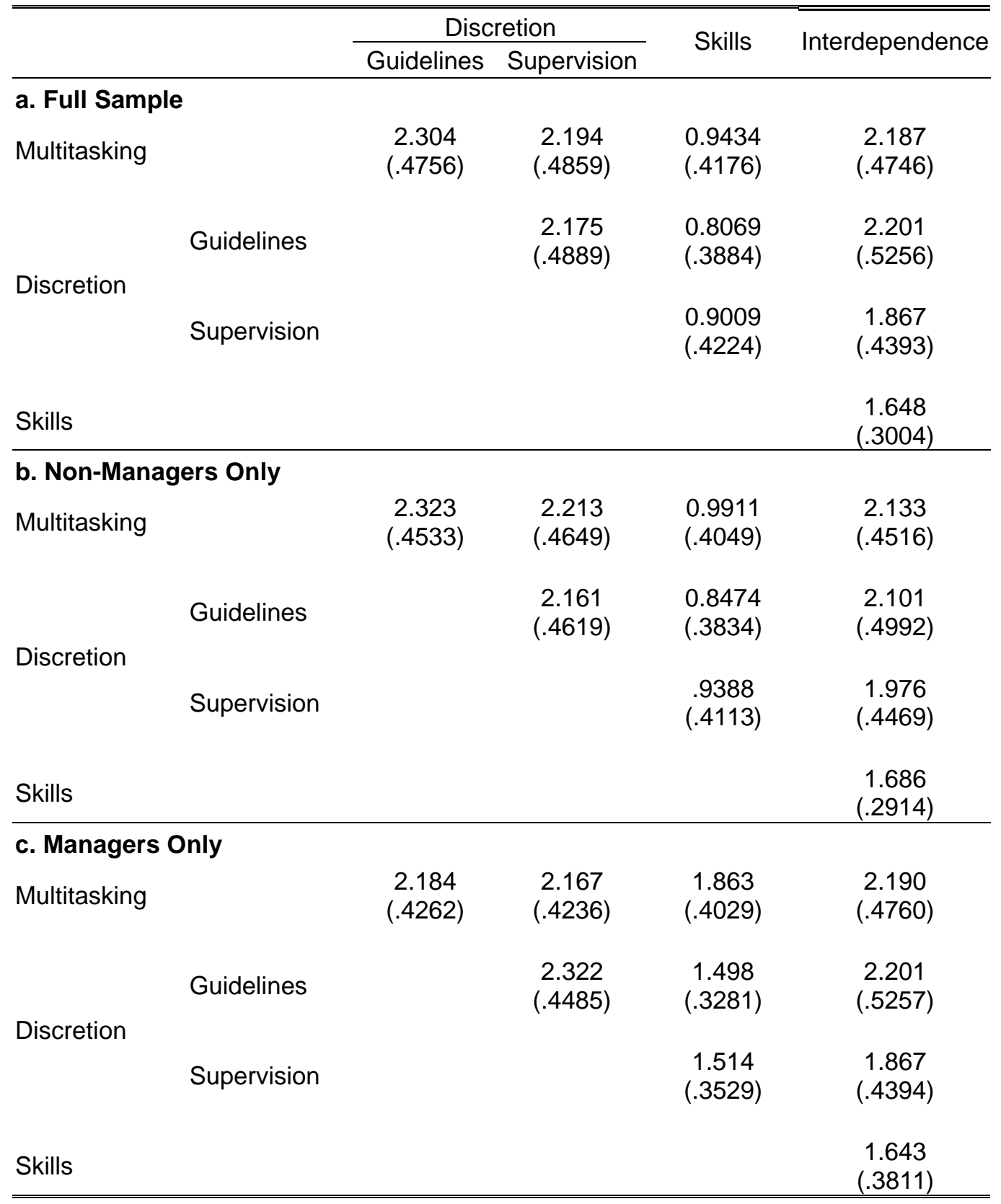

Relationships between factors are coefficients from ordered probits; each cell represents a separate probit. Rows are dependent variables; columns are independent variables. Pseudo- $\mathrm{R}^{2} \mathrm{~s}$ are in parentheses. 
Table 3.

Distribution of Factor Responses (centered around occupation-specific median for each factor)

\begin{tabular}{|c|c|c|c|c|c|c|c|c|c|}
\hline & -2 & -1 & Median & +1 & +2 & +3 & +4 & +5 & +6 \\
\hline Skills & 0.1053 & 0.2571 & 0.1991 & 0.1354 & 0.0703 & 0.1438 & 0.0723 & 0.0160 & 0.0007 \\
\hline Supervision Rec'd & & 0.2164 & 0.4146 & 0.2877 & 0.0713 & 0.0101 & & & \\
\hline Guidelines & & 0.3332 & 0.3611 & 0.2465 & 0.0521 & 0.0071 & & & \\
\hline Multitasking & & 0.1927 & 0.3508 & 0.3567 & 0.0683 & 0.0299 & 0.0015 & & \\
\hline \multirow[t]{3}{*}{ Interdependence } & & 0.3093 & 0.3450 & 0.2851 & 0.0457 & 0.0134 & 0.0015 & & \\
\hline & \multicolumn{9}{|c|}{ Fraction of jobs relative to median } \\
\hline & \multicolumn{3}{|c|}{ Below Median $(\mathrm{MV}=1)$} & \multicolumn{3}{|c|}{ Median $(\mathrm{MV}=2)$} & \multicolumn{3}{|c|}{ Above Median (MV = 3) } \\
\hline Skills & \multicolumn{3}{|c|}{0.3624} & \multicolumn{3}{|c|}{0.1991} & \multicolumn{3}{|c|}{0.4385} \\
\hline Guidelines & \multicolumn{3}{|c|}{0.3332} & \multicolumn{3}{|c|}{0.3611} & \multicolumn{3}{|c|}{0.3057} \\
\hline Multitasking & \multicolumn{3}{|c|}{0.1927} & \multicolumn{3}{|c|}{0.3508} & \multicolumn{3}{|c|}{0.4565} \\
\hline Interdependence & \multicolumn{3}{|c|}{0.3093} & \multicolumn{3}{|c|}{0.3450} & \multicolumn{3}{|c|}{0.3457} \\
\hline
\end{tabular}


Table 4.

Index ( $\Sigma$ MV) of Skills, Guidelines, Multitasking, \& Interdependence

\begin{tabular}{lcc}
\hline \hline Index relative to median & $\begin{array}{c}\text { Fraction of all jobs } \\
(\text { s.e. })\end{array}$ & $\begin{array}{c}\text { Pr(characteristics ran- } \\
\text { domly assigned from } \\
\text { empirical distribution) }\end{array}$ \\
\hline 4 (= LLLL) & $\begin{array}{c}0.0541 \\
(0.0006)\end{array}$ & 0.0072 \\
5 & 0.0697 & 0.0329 \\
& $(0.0007)$ & 0.0955 \\
6 & 0.1109 & \\
& $(0.0009)$ & 0.1700 \\
7 & 0.1488 & 0.0087 \\
8 (= MMMM) & $(0.0010)$ & \\
All other values of index $=8$ & 0.2502 & 0.2096 \\
except MMMM & $(0.0012)$ & \\
9 & 0.0151 & 0.2183 \\
& $(0.0003)$ & 0.1571 \\
10 & 0.1268 & \\
11 & $(0.0009)$ & 0.0720 \\
$12(=\mathrm{HHHH})$ & 0.0796 & 0.0212 \\
\hline \hline
\end{tabular}


Table 5.

Determinants of Modern (HHHH) or Classical (LLLL) Job Design

\begin{tabular}{l|c|c|c|c}
\hline \hline & $\operatorname{Pr}(\mathrm{LLLL})$ & $\operatorname{Pr}(\mathrm{LLLL})$ & $\operatorname{Pr}(\mathrm{HHHH})$ & $\operatorname{Pr}(\mathrm{HHHH})$ \\
\hline Non-profit & -0.1115 & $-0.2801^{5}$ & $-0.2193^{5}$ & $-0.2303^{5}$ \\
Union & $-0.8562^{1}$ & $-0.6336^{1}$ & $-0.1755^{1}$ & $-0.1801^{1}$ \\
Employment/1,000 & $-0.0226^{1}$ & 0.0048 & $0.0820^{1}$ & $0.0387^{1}$ \\
(Employment/1,000) $^{2}$ & $-0.0001^{5}$ & -0.0001 & $-0.0011^{1}$ & $-0.0003^{1}$ \\
Industry controls & $\mathrm{No}$ & Yes & No & Yes \\
Pseudo $\mathrm{R}^{2}$ & .0128 & .0434 & .0109 & .0817 \\
$\mathrm{~N}$ & 42,750 & 40,285 & 42,750 & 40,570 \\
\hline \hline
\end{tabular}

Coefficients from logits. Sample $=$ jobs in multi-establishment firms. Controls are included for \% of jobs in 14 job design clusters as described in Table $5 a$.

${ }^{1}=\mathrm{p}$-value $<0.01 ;{ }^{5}=\mathrm{p}$-value $<0.05 ;{ }^{10}=\mathrm{p}$-value $<0.10$ 
Table 6a.

Effect of Distribution of Other Jobs' Characteristics on Probability of Modern (HHHH) or Classical (LLLL) Job Design

\begin{tabular}{|c|c|c|c|c|c|c|c|c|}
\hline \multirow[t]{2}{*}{ Industry controls } & \multicolumn{2}{|c|}{$\begin{array}{c}\mathrm{Pr}(\mathrm{LLLL}) \\
\text { No }\end{array}$} & \multicolumn{2}{|c|}{$\begin{array}{c}\operatorname{Pr}(\text { LLLL }) \\
\text { Yes }\end{array}$} & \multicolumn{2}{|c|}{$\begin{array}{l}\mathrm{Pr}(\mathrm{HHHH}) \\
\quad \text { No }\end{array}$} & \multicolumn{2}{|c|}{$\begin{array}{c}\operatorname{Pr}(\mathrm{HHHH}) \\
\text { Yes }\end{array}$} \\
\hline & Estab. & Firm & Estab. & Firm & Estab. & Firm & Estab. & Firm \\
\hline $\begin{array}{l}\text { With skill set: } \\
\text { LLLL }\end{array}$ & $3.281^{1}$ & $3.078^{1}$ & $1.958^{1}$ & $1.963^{1}$ & $-0.547^{5}$ & 0.588 & $-0.903^{1}$ & 0.259 \\
\hline $3 \mathrm{~L}, 1 \mathrm{M}$ & $1.262^{1}$ & $1.045^{1}$ & $1.263^{1}$ & $1.009^{1}$ & -0.395 & -0.410 & $-0.573^{5}$ & $-0.604^{10}$ \\
\hline $2 \mathrm{~L}, 2 \mathrm{M}$ & $1.176^{1}$ & 0.015 & $1.135^{1}$ & -0.027 & $-0.573^{1}$ & -0.408 & $-0.576^{1}$ & -0.384 \\
\hline $1 \mathrm{~L}, 3 \mathrm{M}$ & $0.520^{1}$ & 0.175 & $0.577^{1}$ & 0.159 & $-0.758^{1}$ & $-0.800^{1}$ & $-0.749^{1}$ & $-0.696^{1}$ \\
\hline $3 \mathrm{~L}, 1 \mathrm{H}$ & 2.104 & 5.729 & 0.602 & 4.913 & -0.996 & -2.412 & -1.771 & -5.261 \\
\hline $2 \mathrm{H}, 1 \mathrm{M}, 1 \mathrm{~L}$ & 0.870 & 1.696 & 0.448 & 0.772 & 0.495 & 0.611 & 0.474 & 0.780 \\
\hline $2 \mathrm{H}, 2 \mathrm{~L}$ & -0.888 & 0.042 & -2.487 & -4.806 & -11.67 & 7.032 & -9.989 & 6.873 \\
\hline $1 \mathrm{~L}, 2 \mathrm{M}, 1 \mathrm{H}$ & -0.472 & 1.047 & -0.310 & 0.709 & 0.073 & -0.148 & -0.271 & -0.755 \\
\hline $2 \mathrm{~L}, 1 \mathrm{M}, 1 \mathrm{H}$ & -1.639 & 0.145 & -1.226 & -0.236 & -0.171 & 0.977 & -0.812 & 0.004 \\
\hline $3 \mathrm{H}, 1 \mathrm{~L}$ & 0.426 & -0.571 & 0.778 & -0.283 & -2.658 & -2.720 & -2.244 & -1.403 \\
\hline $1 \mathrm{H}, 3 \mathrm{M}$ & $-0.986^{1}$ & -0.059 & $-0.899^{1}$ & 0.172 & $0.427^{1}$ & -0.361 & $0.454^{1}$ & -0.049 \\
\hline $2 \mathrm{H}, 2 \mathrm{M}$ & $-0.841^{1}$ & -0.372 & $-0.896^{1}$ & $-0.928^{1}$ & $1.019^{1}$ & 0.084 & $0.895^{1}$ & -0.158 \\
\hline $3 \mathrm{H}, 1 \mathrm{M}$ & $-0.624^{5}$ & 0.495 & $-0.921^{1}$ & 0.081 & $1.354^{1}$ & 0.200 & $1.255^{1}$ & 0.276 \\
\hline HHHH & $-0.816^{1}$ & $0.970^{1}$ & $-1.038^{1}$ & 0.301 & $3.517^{1}$ & $1.937^{1}$ & $2.726^{1}$ & $1.014^{1}$ \\
\hline Pseudo $\mathrm{R}^{2}$ & $.0 \varsigma$ & & $.0 \mathrm{~s}$ & & .11 & 33 & & 235 \\
\hline $\mathrm{N}$ & 41, & & 40 & 285 & 41, & 421 & 40, & 570 \\
\hline
\end{tabular}

Coefficients from logits. Controls included for non-profit status, unionization, establishment size and its square. Sample $=$ jobs in multi-establishment firms.

${ }^{1}=\mathrm{p}$-value $<0.01 ;{ }^{5}=\mathrm{p}$-value $<0.05 ;{ }^{10}=\mathrm{p}$-value $<0.10$ 
Table 6b.

Effect of Distribution of Other Jobs' Characteristics on Probability of MMMM Job Design

\begin{tabular}{|c|c|c|c|c|}
\hline \multirow[t]{2}{*}{ Industry controls } & \multicolumn{2}{|c|}{$\begin{array}{c}\operatorname{Pr}(\mathrm{MMMM}) \\
\text { No }\end{array}$} & \multicolumn{2}{|c|}{$\begin{array}{c}\operatorname{Pr}(\mathrm{MMMM}) \\
\text { Yes }\end{array}$} \\
\hline & Estab. & Firm & Estab. & Firm \\
\hline $\begin{array}{l}\text { With skill set: } \\
\text { LLLL }\end{array}$ & 0.059 & $-0.453^{5}$ & 0.047 & $-0.617^{1}$ \\
\hline $3 \mathrm{~L}, 1 \mathrm{H}$ & $-5.404^{1}$ & -0.203 & $-5.452^{1}$ & 0.250 \\
\hline $2 \mathrm{H}, 1 \mathrm{M}, 1 \mathrm{~L}$ & -0.386 & -0.361 & -0.522 & -0.678 \\
\hline $2 \mathrm{H}, 2 \mathrm{~L}$ & -0.321 & 1.880 & -0.396 & 1.099 \\
\hline $3 \mathrm{~L}, 1 \mathrm{M}$ & $0.338^{5}$ & $-0.526^{1}$ & 0.280 & $-0.654^{1}$ \\
\hline $2 \mathrm{~L}, 2 \mathrm{M}$ & $0.331^{1}$ & $-0.541^{1}$ & 0.194 & $-0.793^{1}$ \\
\hline $1 \mathrm{~L}, 3 \mathrm{M}$ & $0.422^{1}$ & -0.188 & $0.279^{5}$ & $-0.490^{1}$ \\
\hline MMMM & $1.508^{1}$ & $1.237^{1}$ & $1.185^{1}$ & $0.669^{1}$ \\
\hline $1 \mathrm{H}, 3 \mathrm{M}$ & $0.465^{1}$ & $-0.501^{1}$ & $0.278^{5}$ & $-0.986^{1}$ \\
\hline $2 \mathrm{H}, 2 \mathrm{M}$ & $0.459^{1}$ & $-0.467^{1}$ & $0.454^{1}$ & $-0.535^{1}$ \\
\hline $3 \mathrm{H}, 1 \mathrm{M}$ & $0.427^{1}$ & $-0.777^{1}$ & $0.347^{1}$ & $-1.046^{1}$ \\
\hline $1 \mathrm{~L}, 2 \mathrm{M}, 1 \mathrm{H}$ & -0.068 & $-0.717^{5}$ & -0.007 & $-0.746^{5}$ \\
\hline $2 \mathrm{~L}, 1 \mathrm{M}, 1 \mathrm{H}$ & -0.850 & -1.261 & -0.872 & -1.349 \\
\hline $3 \mathrm{H}, 1 \mathrm{~L}$ & 0.283 & 1.307 & -0.050 & 0.930 \\
\hline Pseudo $R^{2}$ & & 106 & & \\
\hline $\mathrm{N}$ & 41 & 421 & 41 & 298 \\
\hline
\end{tabular}

Coefficients from logits. its. Controls included for non-profit status, unionization, establishment size and its square. Sample $=$ jobs in multi-establishment firms.

${ }^{1}=\mathrm{p}$-value $<0.01 ;{ }^{5}=\mathrm{p}$-value $<0.05 ;{ }^{10}=\mathrm{p}$-value $<0.10$ 
Table 7.

Clustering of Job Design Outside Own 2-digit Occupation

\begin{tabular}{l|ccc|cc}
\hline \hline \multirow{2}{*}{$\begin{array}{c}\text { Proportion of jobs } \\
\text { outside own occu- } \\
\text { pation with same } \\
\text { job design }\end{array}$} & $\begin{array}{c}\text { Multi-establishment firms } \\
\begin{array}{c}\text { Like jobs in } \\
\text { economy ab- }\end{array}\end{array}$ & $\begin{array}{c}\text { Like jobs in firm } \\
\text { absent own } \\
\text { estab. }\end{array}$ & $\begin{array}{c}\text { Like jobs in es- } \\
\text { tablishment } \\
\text { absent own }\end{array}$ & $\begin{array}{c}\text { Single establishment firms } \\
\text { economy absent } \\
\text { own firm }\end{array}$ & $\begin{array}{c}\text { Like jobs in es- } \\
\text { tablishment ab- } \\
\text { sent own }\end{array}$ \\
\hline Job is LLLL & .0525 & .0684 & .0949 & .0526 & .0967 \\
Job is MMMM & .2482 & .2536 & .2513 & .2481 & .2460 \\
Job is HHHH & .0618 & .1292 & .1604 & .0620 & .1132 \\
\hline \hline
\end{tabular}


Table 8.

Effect of Distribution of Other Jobs' Characteristics on Probability of Modern (HHHH) or Classical (LLLL) Job Design: Comparing Jobs Within and Outside Own 2-digit Occupation

\begin{tabular}{|c|c|c|c|c|c|c|}
\hline \multirow{3}{*}{$\begin{array}{l}\text { Peers in } \\
\text { skill set: }\end{array}$} & \multicolumn{3}{|c|}{$\operatorname{Pr}(\mathrm{HHHH})$} & \multicolumn{3}{|c|}{$\operatorname{Pr}($ LLLL $)$} \\
\hline & \multicolumn{2}{|c|}{ Jobs in the establishment } & \multirow[b]{2}{*}{$\begin{array}{l}\text { Jobs in other } \\
\text { establishments } \\
\text { in firm }\end{array}$} & \multicolumn{2}{|c|}{ Jobs in the establishment } & \multirow[b]{2}{*}{$\begin{array}{l}\text { Jobs in other } \\
\text { establishments } \\
\text { in firm }\end{array}$} \\
\hline & $\begin{array}{l}\text { Within own } \\
\text { 2-digit occu- } \\
\text { pation }\end{array}$ & $\begin{array}{c}\text { Outside } \\
\text { own 2-digit } \\
\text { occupation }\end{array}$ & & $\begin{array}{l}\text { Within own } \\
\text { 2-digit oc- } \\
\text { cupation }\end{array}$ & $\begin{array}{c}\text { Outside } \\
\text { own 2-digit } \\
\text { occupation }\end{array}$ & \\
\hline LLLL & $-0.680^{1}$ & $-0.920^{1}$ & 0.153 & $1.889^{1}$ & $0.804^{1}$ & $2.047^{1}$ \\
\hline $3 \mathrm{~L}, 1 \mathrm{M}$ & $-1.291^{1}$ & -0.405 & -0.467 & $0.619^{1}$ & $1.009^{1}$ & $0.901^{1}$ \\
\hline $2 \mathrm{~L}, 2 \mathrm{M}$ & $-0.912^{1}$ & $-0.380^{1}$ & -0.239 & $0.616^{1}$ & $0.832^{1}$ & -0.072 \\
\hline $1 \mathrm{~L}, 3 \mathrm{M}$ & $-0.423^{1}$ & $-0.718^{1}$ & $-0.578^{5}$ & -0.065 & $0.503^{1}$ & 0.084 \\
\hline $3 \mathrm{~L}, 1 \mathrm{H}$ & 1.002 & -0.701 & -4.816 & 0.683 & 3.429 & 2.856 \\
\hline $\begin{array}{l}2 \mathrm{H}, 1 \mathrm{M}, \\
1 \mathrm{~L}\end{array}$ & -0.282 & -0.414 & 1.124 & & 0.564 & 1.417 \\
\hline $2 \mathrm{H}, 2 \mathrm{~L}$ & & -10.16 & 7.424 & -0.795 & -2.734 & -4.008 \\
\hline $\begin{array}{l}1 \mathrm{~L}, 2 \mathrm{M}, \\
1 \mathrm{H}\end{array}$ & $-0.802^{5}$ & -0.257 & -0.991 & 0.446 & 0.134 & 1.183 \\
\hline $\begin{array}{l}2 \mathrm{~L}, 1 \mathrm{M}, \\
1 \mathrm{H}\end{array}$ & -0.281 & -1.166 & 0.256 & -0.684 & -1.215 & 0.805 \\
\hline $3 \mathrm{H}, 1 \mathrm{~L}$ & 0.595 & -1.936 & -0.731 & -0.737 & 1.197 & -0.398 \\
\hline $1 \mathrm{H}, 3 \mathrm{M}$ & -0.012 & 0.211 & 0.034 & $-0.774^{1}$ & $-0.435^{1}$ & 0.159 \\
\hline $2 \mathrm{H}, 2 \mathrm{M}$ & $0.446^{1}$ & $0.469^{1}$ & -0.169 & -0.245 & $-0.672^{1}$ & $-1.086^{1}$ \\
\hline $3 \mathrm{H}, 1 \mathrm{M}$ & $0.255^{1}$ & $0.725^{1}$ & 0.466 & $-0.727^{1}$ & $-0.630^{1}$ & 0.095 \\
\hline $\mathrm{HHHH}$ & $1.885^{1}$ & $0.899^{1}$ & $1.235^{1}$ & $-0.404^{1}$ & $-0.801^{1}$ & 0.308 \\
\hline $\begin{array}{l}\text { Industry } \\
\text { Included? }\end{array}$ & & Yes & & & Yes & \\
\hline $\mathrm{R}^{2}$ & & .1513 & & & .1287 & \\
\hline $\mathrm{N}$ & & 39,455 & & & 39,169 & \\
\hline
\end{tabular}

Results from logits. Sample $=$ jobs in multi-establishment firms.

${ }^{1}=p$-value $<0.01 ;{ }^{5}=p$-value $<0.05 ;{ }^{10}=p$-value $<0.10$ 
Table 9.

Clustering of HHHH and LLLL Job Design Outside Own 2-digit Occupation

\begin{tabular}{|c|c|c|c|c|c|c|}
\hline $\begin{array}{l}\text { Proportion of other } \\
\text { jobs with same job } \\
\text { characteristics mix }\end{array}$ & $\begin{array}{l}\text { All jobs in } \\
\text { economy, } \\
\text { not in firm }\end{array}$ & $\begin{array}{c}\mathrm{HHHH} \\
\text { All jobs in } \\
\text { firm, not in } \\
\text { estab. }\end{array}$ & $\begin{array}{l}\text { All other } \\
\text { jobs in es- } \\
\text { tab. }\end{array}$ & $\begin{array}{l}\text { All jobs in } \\
\text { economy, } \\
\text { not in firm }\end{array}$ & $\begin{array}{c}\text { LLLL } \\
\text { All jobs in } \\
\text { firm, not in } \\
\text { estab. }\end{array}$ & $\begin{array}{l}\text { All other } \\
\text { jobs in es- } \\
\text { tab. }\end{array}$ \\
\hline All workers & .0618 & .1292 & .1604 & .0525 & .0684 & .0949 \\
\hline Public Admin. & .0619 & .0814 & .1052 & .0542 & .0471 & .2827 \\
\hline Executives & .0582 & .1322 & .1725 & .0522 & .0525 & .0853 \\
\hline Mgmt-Related & .0622 & .2091 & .2578 & .0511 & .0685 & .0957 \\
\hline Engineers & .0611 & .1718 & .2287 & .0533 & .0609 & .0934 \\
\hline Math/CS & .0618 & .3629 & .4076 & .0531 & .0617 & .1037 \\
\hline Natural Science & .0620 & .1568 & .2044 & .0538 & .0622 & .1010 \\
\hline Health Diagnostic & .0627 & .0789 & .1000 & .0540 & .0643 & .0645 \\
\hline Health Treatment & .0645 & .0705 & .0527 & .0551 & .0620 & .0937 \\
\hline University Professor & .0615 & .0815 & .1025 & .0540 & .0742 & .0676 \\
\hline Teachers & .0645 & .0330 & .1184 & .0535 & .0358 & .1806 \\
\hline Lawyer/Judge & .0624 & .0658 & .1538 & .0538 & .0502 & .0948 \\
\hline Other Professional & .0626 & .1238 & .1821 & .0526 & .0839 & .1014 \\
\hline Health Technology & .0628 & .0921 & .0900 & .0542 & .0447 & .0705 \\
\hline Engineering Tech. & .0629 & .1888 & .2411 & .0538 & .0411 & .0819 \\
\hline Other Technology & .0622 & .1847 & .1712 & .0534 & .0770 & .0768 \\
\hline Sales Manager & .0620 & .0447 & .0295 & & & \\
\hline Finance/Bus. Sales & .0619 & .0323 & .0560 & .0544 & .0928 & .1286 \\
\hline Service Sales & .0617 & .3464 & .3471 & .0535 & .0230 & .0133 \\
\hline Retail Sales & .0647 & .0815 & .1174 & .0563 & .1347 & .1667 \\
\hline Other Sales & .0626 & .0289 & .0917 & .0540 & .1036 & .0903 \\
\hline Admin. Supervisor & .0628 & .1375 & .1705 & .0546 & .0039 & 0 \\
\hline Computer Operator & & & & .0541 & .0583 & .0632 \\
\hline Secretary & .0621 & .1011 & .1517 & .0545 & .1561 & .1967 \\
\hline Records & .0630 & .1128 & .1102 & .0542 & .1111 & .1198 \\
\hline Mail Distribution & .0625 & .0243 & .0863 & & & \\
\hline Other Admin. & .0640 & .1354 & .1675 & .0497 & .0742 & .0986 \\
\hline Protective Services & .0625 & .1066 & .1255 & .0546 & .0763 & .0688 \\
\hline Food Services & .0638 & .0540 & .0703 & .0566 & .0183 & 0 \\
\hline Health Services & .0632 & .1454 & .1444 & .0556 & 0 & 0 \\
\hline Building Services & .0613 & .0837 & .0948 & .0559 & .0067 & .0417 \\
\hline Personal Services & .0612 & .0819 & .0588 & .0551 & .0258 & .025 \\
\hline Mechanic & .0648 & .1907 & .1667 & .0535 & .0586 & .0759 \\
\hline Construction & .0636 & .1199 & .1972 & .0541 & .0340 & .0226 \\
\hline Other Precision & .0638 & .1166 & .2046 & .0535 & .0731 & .0879 \\
\hline Machine Operator & .0622 & .1166 & .1810 & .0533 & .0310 & .0775 \\
\hline Assembler & .0615 & .0913 & .1267 & .0546 & .0471 & .1162 \\
\hline Vehicle Operator & .0629 & .1348 & .1152 & .0544 & .1163 & .0526 \\
\hline Other Transportation & .0629 & .0825 & .1821 & .0543 & .0472 & .1688 \\
\hline Construction Laborer & .0623 & .0890 & .0434 & & & \\
\hline Handlers & .0613 & .0689 & .0746 & & & \\
\hline Other Laborer & .0622 & .0768 & .1424 & & & \\
\hline Farm Laborer & .0623 & .1095 & .0366 & .0541 & .3333 & 0 \\
\hline Forestry/Fishing & & & & .0540 & .625 & 0 \\
\hline
\end{tabular}

Sample = all jobs, by 2-digit occupation . 
Table A1.

Relationships Between Pairs of Job Design Attributes Controlling for Industry or Occupation

\begin{tabular}{|c|c|c|c|c|c|c|c|c|}
\hline & \multicolumn{4}{|c|}{ Controlling for Industry } & \multicolumn{4}{|c|}{ Controlling for Occupation } \\
\hline & Guidelines & Supervision & Skills & $\begin{array}{l}\text { Interde- } \\
\text { pendence }\end{array}$ & Guidelines & Supervision & Skills & $\begin{array}{l}\text { Interde- } \\
\text { pendence }\end{array}$ \\
\hline \multicolumn{9}{|c|}{ a. Full Sample } \\
\hline Multitasking & $\begin{array}{c}2.264 \\
(0.4899)\end{array}$ & $\begin{array}{c}2.168 \\
(0.5068)\end{array}$ & $\begin{array}{c}0.9600 \\
(0.4450)\end{array}$ & $\begin{array}{c}2.230 \\
(.4956)\end{array}$ & $\begin{array}{c}2.093 \\
(0.5514)\end{array}$ & $\begin{array}{c}1.979 \\
(0.5566)\end{array}$ & $\begin{array}{c}1.530 \\
(0.5387)\end{array}$ & $\begin{array}{c}2.177 \\
(.4795)\end{array}$ \\
\hline Guidelines & & $\begin{array}{c}2.168 \\
(0.5068)\end{array}$ & $\begin{array}{c}0.8450 \\
(0.4235)\end{array}$ & $\begin{array}{c}2.229 \\
(.5410)\end{array}$ & & $\begin{array}{c}2.024 \\
(0.5498)\end{array}$ & $\begin{array}{c}1.533 \\
(0.538)\end{array}$ & $\begin{array}{c}2.189 \\
(.5290)\end{array}$ \\
\hline Supervision & & & $\begin{array}{c}0.9138 \\
(0.4367)\end{array}$ & $\begin{array}{c}1.896 \\
(.4589)\end{array}$ & & & $\begin{array}{c}1.335 \\
(0.5106)\end{array}$ & $\begin{array}{c}1.853 \\
(.4411)\end{array}$ \\
\hline Skills & & & & $\begin{array}{c}1.657 \\
(.3350) \\
\end{array}$ & & & & $\begin{array}{c}1.620 \\
(.5656)\end{array}$ \\
\hline \multicolumn{9}{|c|}{ b. Non-Managers } \\
\hline Multitasking & $\begin{array}{c}2.264 \\
(.4702)\end{array}$ & $\begin{array}{c}2.171 \\
(.4879)\end{array}$ & $\begin{array}{c}1.012 \\
(.4387)\end{array}$ & $\begin{array}{c}2.081 \\
(.4741)\end{array}$ & $\begin{array}{c}2.111 \\
(.5322)\end{array}$ & $\begin{array}{c}1.998 \\
(.5408)\end{array}$ & $\begin{array}{c}1.497 \\
(.5230)\end{array}$ & $\begin{array}{c}1.916 \\
(.5263)\end{array}$ \\
\hline Guidelines & & $\begin{array}{c}2.146 \\
(.4875)\end{array}$ & $\begin{array}{c}.9080 \\
(.4298)\end{array}$ & $\begin{array}{c}2.063 \\
(.5200)\end{array}$ & & $\begin{array}{c}1.999 \\
(.5285)\end{array}$ & $\begin{array}{c}1.672 \\
(.5491)\end{array}$ & $\begin{array}{c}1.926 \\
(.5519)\end{array}$ \\
\hline Supervision & & & $\begin{array}{c}.9534 \\
(.4308)\end{array}$ & $\begin{array}{c}1.950 \\
(.4666)\end{array}$ & & & $\begin{array}{c}1.403 \\
(.5033)\end{array}$ & $\begin{array}{c}1.775 \\
(.5163)\end{array}$ \\
\hline Skills & & & & $\begin{array}{c}1.695 \\
(.3367)\end{array}$ & & & & $\begin{array}{c}1.679 \\
(.5509)\end{array}$ \\
\hline \multicolumn{9}{|c|}{ c. Managers Only } \\
\hline Multitasking & $\begin{array}{l}2.186 \\
(.4456)\end{array}$ & $\begin{array}{c}2.226 \\
(.4553)\end{array}$ & $\begin{array}{c}1.883 \\
(.4210)\end{array}$ & $\begin{array}{c}2.234 \\
(.4969)\end{array}$ & $\begin{array}{c}2.172 \\
(.4305)\end{array}$ & $\begin{array}{l}2.154 \\
(.4301)\end{array}$ & $\begin{array}{c}1.856 \\
(.4073)\end{array}$ & $\begin{array}{c}2.179 \\
(.4809)\end{array}$ \\
\hline Guidelines & & $\begin{array}{c}2.362 \\
(.4725)\end{array}$ & $\begin{array}{c}1.504 \\
(.3467)\end{array}$ & $\begin{array}{c}2.229 \\
(.5411)\end{array}$ & & $\begin{array}{l}2.310 \\
(.4541)\end{array}$ & $\begin{array}{c}1.489 \\
(.3334)\end{array}$ & $\begin{array}{c}2.189 \\
(.5292)\end{array}$ \\
\hline Supervision & & & $\begin{array}{c}1.552 \\
(.3770)\end{array}$ & $\begin{array}{c}1.896 \\
(.4591)\end{array}$ & & & $\begin{array}{c}1.514 \\
(.3564)\end{array}$ & $\begin{array}{c}1.854 \\
(.4413)\end{array}$ \\
\hline Skills & & & & $\begin{array}{r}1.655 \\
(.4128) \\
\end{array}$ & & & & $\begin{array}{c}1.628 \\
(.3874) \\
\end{array}$ \\
\hline
\end{tabular}

Relationships between factors are coefficients from fixed-effect ordered probits; each cell represents a separate probit. Rows are dependent variables; columns are independent variables. Pseudo- ${ }^{2}$ 's are in parentheses. The 1990 U.S. Census 3-digit industry and occupation codes were used to define the industry and occupation controls. 
Table A2.

Effect of Distribution of Other Jobs' Characteristics on Probability of HHHH or LLLL Job Design

\begin{tabular}{|c|c|c|c|c|c|c|c|c|}
\hline \multirow{3}{*}{$\begin{array}{l}\text { Industry controls } \\
\% \text { other jobs with: }\end{array}$} & \multicolumn{2}{|c|}{$\operatorname{Pr}(\mathrm{LLLL})$} & \multicolumn{2}{|c|}{$\operatorname{Pr}(\mathrm{LLLL})$} & \multicolumn{2}{|c|}{ 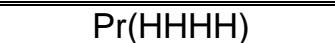 } & \multicolumn{2}{|c|}{$\operatorname{Pr}(\mathrm{HHHH})$} \\
\hline & \multicolumn{2}{|c|}{ No } & \multicolumn{2}{|c|}{ Yes } & \multicolumn{2}{|c|}{ No } & \multicolumn{2}{|c|}{ Yes } \\
\hline & Estab. & Firm & Estab. & Firm & Estab. & Firm & Estab. & Firm \\
\hline LLLL & $2.930^{1}$ & $3.034^{1}$ & $2.039^{1}$ & $1.982^{1}$ & $-0.7171^{1}$ & .3645 & $-0.8802^{1}$ & .2058 \\
\hline MLLL & $1.074^{1}$ & $1.625^{1}$ & $.9392^{1}$ & $1.254^{1}$ & $-0.7024^{5}$ & $-1.345^{1}$ & $-0.8194^{5}$ & $-1.223^{5}$ \\
\hline LMLL & $1.844^{1}$ & .2090 & $1.738^{1}$ & -0.1919 & -0.2427 & $-0.9928^{10}$ & -0.4628 & $-1.153^{10}$ \\
\hline LLML & $.9338^{10}$ & .1835 & $1.234^{1}$ & .5774 & $-1.234^{10}$ & -0.1717 & -0.9048 & .0405 \\
\hline LLLM & $.9570^{10}$ & 1.160 & $1.169^{5}$ & $2.239^{1}$ & .4330 & .6796 & .2028 & .6820 \\
\hline LLMM & $1.122^{1}$ & .3567 & $1.133^{1}$ & -0.0145 & $-1.024^{1}$ & $-1.003^{1}$ & $-0.8834^{1}$ & $-0.7334^{10}$ \\
\hline LMLM & .9415 & 1.622 & .7171 & 1.029 & $-1.824^{10}$ & .5012 & $-2.455^{5}$ & -0.1444 \\
\hline LMML & $2.303^{1}$ & -1.604 & $2.426^{1}$ & -1.600 & $-1.629^{10}$ & -0.2104 & $-1.948^{10}$ & -1.410 \\
\hline MLLM & $.7638^{10}$ & -0.6311 & $.8967^{5}$ & -0.7383 & -0.6879 & .4281 & -0.4200 & $.8707^{10}$ \\
\hline MLML & .3937 & .9660 & .6890 & 1.262 & $-1.576^{5}$ & $-1.614^{10}$ & $-1.537^{5}$ & -0.7724 \\
\hline MMLL & $1.591^{1}$ & -0.1566 & $1.351^{1}$ & -0.2677 & .4982 & .1221 & .1671 & -0.4334 \\
\hline LMMM & $.7535^{1}$ & $.6972^{5}$ & $.7321^{5}$ & .4653 & -0.3561 & $-1.106^{1}$ & -0.2394 & $-0.8151^{10}$ \\
\hline MLMM & $.6803^{1}$ & $-0.7866^{5}$ & $.6667^{1}$ & $-0.7356^{5}$ & $-0.9819^{1}$ & $-1.174^{1}$ & $-0.7175^{1}$ & $-0.5592^{10}$ \\
\hline MMLM & .3717 & .7183 & .2871 & .2194 & -0.3650 & -0.8727 & -0.4987 & $-1.393^{5}$ \\
\hline MMML & .0673 & $1.344^{5}$ & .2761 & .6067 & $-1.610^{1}$ & .4538 & $-1.978^{1}$ & .6151 \\
\hline LLLH & 4.776 & -110.3 & -0.9032 & -150.8 & 1.185 & 2.907 & 1.769 & .1019 \\
\hline LLHL & 3.561 & 6.108 & 2.391 & 1.221 & & -4.927 & & -46.84 \\
\hline LHLL & 1.657 & 4.927 & 1.529 & 5.169 & -0.8927 & -0.6115 & -1.127 & -1.811 \\
\hline \multicolumn{9}{|l|}{ HLLL } \\
\hline LLHH & -0.6134 & 6.032 & -4.319 & 2.270 & -7.676 & 7.197 & -8.787 & 8.989 \\
\hline \multicolumn{9}{|c|}{ LHHL, HLLH, HLHL have no observations } \\
\hline HHLL & & & & & & -38.19 & & -51.80 \\
\hline $\mathrm{LHHH}$ & -0.3998 & -17.99 & -0.1042 & -18.45 & -5.380 & -15.898 & -5.326 & -17.13 \\
\hline HLHH & 2.028 & 1.647 & 2.523 & 2.622 & 1989 & -1.965 & 2.308 & 2.711 \\
\hline $\mathrm{HHLH}$ & -1.508 & 11.60 & -1.463 & $18.17^{10}$ & -3.642 & 2.226 & -5.912 & .3935 \\
\hline $\mathrm{HHHL}$ & .6190 & -5.713 & -0.4054 & -19.07 & -0.3951 & 16.01 & & 12.89 \\
\hline HMLL & 7.553 & -20.25 & 9.296 & -13.67 & -7.700 & .0131 & -8.809 & -0.7919 \\
\hline HLLM & -3.164 & & -9.150 & & 1.100 & & 2.320 & \\
\hline HLML & & 16.31 & & 17.72 & 1.672 & 4.573 & .0613 & 1.326 \\
\hline LLMH & -1.218 & 1.124 & -1.668 & 1.138 & 1.610 & .4258 & -1.272 & -2.921 \\
\hline LLHM & -2.698 & -6.065 & -2.379 & -4.521 & $6.582^{1}$ & 5.145 & $5.594^{5}$ & 1.868 \\
\hline \multicolumn{9}{|l|}{ LMLH } \\
\hline LMHL & -6.866 & 7.909 & -8.165 & 3.076 & -0.5411 & -0.6187 & -1.655 & -1.677 \\
\hline LHLM & -1.098 & -7.354 & -1.007 & -10.33 & -5.564 & -1.287 & -8.235 & -4.626 \\
\hline LHML & .2737 & -1.477 & 1.737 & -0.4743 & 1.080 & -2.689 & .2264 & -4.215 \\
\hline MLLH & & & & & & 3.936 & & 3.187 \\
\hline MLHL & & -17.15 & & -7.612 & -10.22 & 1.975 & -11.02 & 4.926 \\
\hline MHLL & .4121 & -0.3604 & .3802 & .8369 & -0.5419 & $2.338^{5}$ & -1.262 & 1.602 \\
\hline \multicolumn{9}{|c|}{ (continued on next page) } \\
\hline
\end{tabular}




\begin{tabular}{|c|c|c|c|c|c|c|c|c|}
\hline LHMM & 1.182 & 1.492 & 1.271 & .7813 & 1.262 & .1630 & .9830 & -0.7765 \\
\hline LMHM & -0.0570 & -1.117 & .3534 & -1.771 & $3.639^{1}$ & -0.6835 & $4.194^{1}$ & -2.147 \\
\hline MLMH & $-8.101^{5}$ & $4.030^{5}$ & $-8.666^{5}$ & $4.437^{5}$ & $-5.267^{10}$ & -0.2540 & $-5.238^{10}$ & .8430 \\
\hline LMMH & -2.468 & 1.155 & -2.037 & $2.536^{10}$ & -0.2871 & -4.371 & -0.3278 & -4.442 \\
\hline MLHM & -2.994 & -1.163 & $-5.063^{5}$ & -5.333 & -0.6571 & -2.246 & -0.7093 & -1.076 \\
\hline MMLH & -1.838 & $2.712^{10}$ & -3.646 & 2.362 & .0641 & -2.400 & -1.248 & -3.298 \\
\hline MMHL & -1.082 & .4636 & -1.732 & -0.9096 & -0.2973 & 1.884 & .4413 & 2.465 \\
\hline MHLM & 1.829 & -0.6053 & $2.773^{10}$ & .7817 & -0.4844 & .9438 & -1.331 & .3649 \\
\hline MHML & .5310 & 1.622 & 1.035 & 1.637 & .3212 & .8711 & .2347 & .7884 \\
\hline HMML & -1.089 & -0.5937 & -3.585 & -0.2369 & -3.512 & 1.572 & -3.183 & -0.0244 \\
\hline HLMM & -0.5964 & -3.946 & .0959 & -4.768 & -1.776 & -0.0359 & -2.187 & .2914 \\
\hline HMLM & 3.021 & 1.560 & 3.412 & 3.604 & $-25.77^{10}$ & -0.7417 & $-25.69^{10}$ & -3.794 \\
\hline \multicolumn{9}{|c|}{ MMMM = base case } \\
\hline LHHM & 3.748 & 8.707 & 2.430 & 2.675 & -5.210 & 6.151 & -5.910 & -4.125 \\
\hline LHMH & 7.090 & -2.587 & 2.396 & -11.98 & -9.246 & 5.130 & -7.530 & 11.95 \\
\hline LMHH & -2.878 & 2.628 & -6.881 & .1668 & -7.683 & -7.829 & -4.645 & -4.754 \\
\hline MHLH & & 1.380 & & -2.372 & & & & \\
\hline $\mathrm{MLHH}$ & $2.908^{10}$ & .1066 & 2.473 & -3.005 & .3599 & .9696 & .3063 & .3924 \\
\hline MHHL & -0.3631 & -6.298 & -1.121 & -5.609 & 1.926 & 1.094 & 1.941 & 1.828 \\
\hline HLMH & .5681 & .3618 & 1.290 & 1.502 & .7120 & -4.041 & 1.926 & .6389 \\
\hline HLHM & -6.722 & 2.506 & -5.985 & -0.5327 & 3.174 & .1946 & 2.531 & 1.259 \\
\hline \multicolumn{9}{|l|}{ HMLH } \\
\hline HMHL & -2.667 & $3.272^{10}$ & -1.967 & $5.469^{5}$ & 1.292 & 1.999 & 1.058 & 1.548 \\
\hline HHLM & 3.278 & 3.184 & 3.177 & 1.191 & -1.645 & 7.408 & -1.038 & 6.143 \\
\hline HHML & $10.06^{10}$ & -8.923 & 6.349 & -11.11 & 8.463 & -66.81 & 6.946 & -61.94 \\
\hline HMMM & -0.1239 & .4239 & -0.4195 & -0.0931 & $.9412^{1}$ & -0.0846 & $.7902^{1}$ & -0.2015 \\
\hline MHMM & $-0.9904^{1}$ & .4371 & $-0.7566^{10}$ & $.9236^{10}$ & .2081 & .2558 & -0.0889 & -0.2044 \\
\hline MMHM & $-3.332^{1}$ & -0.6602 & $-3.068^{1}$ & -0.1621 & .5723 & $-1.473^{1}$ & $.9796^{1}$ & -0.8266 \\
\hline MMMH & -0.2135 & $-0.8186^{5}$ & $-0.7285^{10}$ & .3747 & -0.2489 & -0.2248 & .0724 & \\
\hline HHMM & -0.5866 & .3929 & $-0.8696^{10}$ & -0.7068 & $1.394^{1}$ & $1.044^{5}$ & $1.220^{1}$ & .3106 \\
\hline $\mathrm{HMMH}$ & -1.334 & -0.0209 & -1.449 & .2831 & .2818 & .2708 & .0974 & .0132 \\
\hline HMHM & -0.1646 & .2349 & -1.068 & -0.2462 & $1.596^{1}$ & -1.080 & $1.211^{1}$ & $-1.862^{5}$ \\
\hline $\mathrm{MHMH}$ & $-2.012^{10}$ & $-2.688^{10}$ & $-1.823^{10}$ & $-3.515^{5}$ & .7688 & .7720 & .7921 & .5786 \\
\hline MHHM & $-1.432^{5}$ & $-1.338^{10}$ & $-1.627^{5}$ & $-1.857^{5}$ & $-0.8736^{5}$ & $-1.313^{5}$ & -0.4818 & -0.3751 \\
\hline МMHH & -0.2920 & -0.2982 & -0.5473 & -0.5960 & $1.743^{1}$ & $1.034^{1}$ & $1.537^{1}$ & .5108 \\
\hline $\mathrm{MHHH}$ & $-0.9279^{5}$ & -0.0668 & $-1.147^{5}$ & .1604 & $.7060^{5}$ & .1495 & $.7671^{1}$ & .6435 \\
\hline $\mathrm{HMHH}$ & -0.1202 & $1.402^{1}$ & -0.8495 & .5875 & $2.171^{1}$ & $.6445^{10}$ & $2.113^{1}$ & .5864 \\
\hline $\mathrm{HHMH}$ & $-1.212^{5}$ & -0.1656 & $-1.075^{10}$ & -0.5682 & -0.0479 & $.6851^{10}$ & -0.1722 & .5475 \\
\hline $\mathrm{HHHM}$ & -0.5029 & -0.5579 & -0.4967 & -0.5042 & $1.640^{1}$ & $2.222^{1}$ & $2.082^{1}$ & -0.6012 \\
\hline НHHH & $-1.076^{1}$ & $.7060^{5}$ & $-1.252^{1}$ & .3912 & $3.054^{1}$ & $1.640^{1}$ & $2.483^{1}$ & $1.101^{1}$ \\
\hline$R^{2}$ & \multicolumn{2}{|c|}{.1029} & \multicolumn{2}{|c|}{.1225} & \multicolumn{2}{|c|}{.1270} & \multicolumn{2}{|c|}{.1389} \\
\hline$N$ & \multicolumn{2}{|c|}{41,164} & \multicolumn{2}{|c|}{40,028} & \multicolumn{2}{|c|}{41,323} & \multicolumn{2}{|c|}{40,472} \\
\hline
\end{tabular}

${ }^{1}=$ p-value $<0.01 ;{ }^{5}=$ p-value $<0.05 ;{ }^{10}=p$-value $<0.10$ 